\title{
Periodontal Analysis of Teeth with Biological Space Invasion submitted to Root Extrusion and Prosthetic Rehabilitation: Literature Review
} Análise Periodontal de Dentes com Invasão de Espaço Biológico submetidos à Extrusão Radicular e Reabilitação Protética: Revisão da Literatura

Análisis Periodontal de Dientes con Invasión Biológica del Espacio Sometidos a Extrusión Radicular y Rehabilitación Protésica: Revisión de la Literatura

Laura Lourenço MOREL

Faculdade de Odontologia, UFPel Universidade Federal de Pelotas, 96015-560 Pelotas - RS, Brasil https://orcid.org/0000-0002-4855-311X Lucas Jardim da SILVA Faculdade de Odontologia, UFPel Universidade Federal de Pelotas, 96015-560 Pelotas - RS, Brasi Giovane Hisse GOMES Professor Doutor, Departamento de Odontologia, Faculdade de Odontologia, UCPel Universidade Católica de Pelotas, 96055-000 Pelotas - RS, Brasil https://orcid.org/0000-0001-9580-6100

Josué MARTOS

Professor Titular, Departamento de Semiologia e Clínica, Faculdade de Odontologia, UFPel Universidade Federal de Pelotas, 96015-560 Pelotas - RS, Brasil Abstract https://orcid.org/000-0003-1988-9463

Aim: The purpose of this literature review was to identify whether root traction may maintain the periodontal health of teeth with invasion of supracrestal tissue attachment and prosthetically rehabilitated. Materials and Methods: A literature review was conducted, in which the periodontal effects of root traction provided on the ability to maintain teeth with invasion of supracrestal tissue attachment and prosthetically rehabilitated were searched in the electronic databases Scopus, PubMed, Web of Science, EMBASE, Scielo and Cochrane using the Mesh descriptors "orthodontic extrusions", "forced eruption" and "crown lengthening". The inclusion criteria considered studies published in English or Spanish that presented the relationship between root traction and the effect on periodontal health in prosthetically rehabilitated teeth. After collection of articles, they were evaluated by three reviewers, who selected the studies according to their relevance according to criteria as type of study, root traction present, rehabilitation with single fixed prosthesis and period of clinical follow-up. Results: A total of 644 references were identified and after exclusion according to eligibility criteria, 33 papers covered all parameters adopted and were included in the qualitative analysis. Satisfactory prosthetic rehabilitation, associated with periodontal health after root traction, could be observed in all studies, notably with variation only in the follow-up time observed up to the first six months, $1,2,3$ and up to 4 years. Conclusions: Root traction is a conservative and effective tool in the maintenance of periodontal health in teeth with invasion of supracrestal tissue attachment and prosthetically rehabilitated.

Descriptors: Periodontium; Tooth Eruption; Orthodontic Extrusion; Crown Lengthening; Dental Prosthesis.

\section{Resumo}

Objetivo: O objetivo desta revisão de literatura foi identificar se a tração radicular pode manter a saúde periodontal de dentes com invasão do tecido de inserção supracrestal e reabilitados protéticamente. Materiais e Métodos: Foi realizada uma revisão de literatura, na qual os efeitos periodontais do tracionamento radicular proporcionado na capacidade de manter dentes com invasão de tecido supracrestal e reabilitados protéticamente foram pesquisados nas bases de dados eletrônicas Scopus, PubMed, Web of Science, EMBASE, Scielo e Cochrane utilizando os descritores Mesh "extrusões ortodônticas", "erupção forçada" e "alongamento da coroa". Os critérios de inclusão consideraram estudos publicados em inglês ou espanhol que apresentassem a relação entre a tração radicular e o efeito na saúde periodontal em dentes reabilitados protéticamente. Após a coleta dos artigos, os mesmos foram avaliados por três revisores, que selecionaram os estudos de acordo com sua relevância segundo critérios como tipo de estudo, tração radicular presente, reabilitação com prótese fixa única e tempo de acompanhamento clínico. Resultados: Foram identificadas 644 referências e após exclusão segundo critérios de elegibilidade, 33 artigos contemplaram todos os parâmetros adotados e foram incluídos na análise qualitativa. A reabilitação protética satisfatória, associada à saúde periodontal após a tração radicular, pôde ser observada em todos os estudos, notadamente com variação apenas no tempo de acompanhamento observado até os primeiros seis meses, 1, 2, 3 e até 4 anos. Conclusões: O tracionamento radicular é uma ferramenta conservadora e eficaz na manutenção da saúde periodontal em dentes com invasão de tecido de inserção supracrestal e reabilitados protéticamente.

Descritores: Periodonto; Erupção Dentária; Extrusão Ortodôntica; Aumento da Coroa Clínica; Prótese Dentária.

\section{Resumen}

Objetivo: El propósito de esta revisión de la literatura fue identificar si la tracción radicular puede mantener la salud periodontal de los dientes con invasión del tejido de inserción supracrestal y rehabilitados protésicamente. Materiales y Métodos: Se realizó una revisión bibliográfica, en la cual se buscó en las bases de datos electrónicas Scopus, PubMed, Web of Science, EMBASE, Scielo y Cochrane utilizando los descriptores de Mesh "extrusiones de ortodoncia", "erupción forzada" y "alargamiento de corona". Los criterios de inclusión consideraron estudios publicados en inglés o español que presentaran la relación entre la tracción radicular y el efecto sobre la salud periodontal en dientes rehabilitados protésicamente. Luego de la recolección de los artículos, fueron evaluados por tres revisores, quienes seleccionaron los estudios según su relevancia según criterios como tipo de estudio, tracción radicular presente, rehabilitación con prótesis fija única y período de seguimiento clínico. Resultados: Se identificaron un total de 644 referencias y después de la exclusión según los criterios de elegibilidad, 33 artículos cubrieron todos los parámetros adoptados y se incluyeron en el análisis cualitativo. La rehabilitación protésica satisfactoria, asociada con la salud periodontal después de la tracción radicular, se pudo observar en todos los estudios, notablemente con variación solo en el tiempo de seguimiento observado hasta los primeros seis meses, 1, 2, 3 y hasta 4 años. Conclusiones: La tracción radicular es una herramienta conservadora y eficaz en el mantenimiento de la salud periodontal en dientes con invasión del tejido de inserción supracrestal y rehabilitados protésicamente.

Descriptores: Periodoncia; Erupción Dental; Extrusión Ortodóntica; Alargamiento de Corona; Prótesis Dental.

INTRODUCTION

The full knowledge on the biological dimensions of the periodontium reveals that preservation of the supracrestal tissue attachment is fundamental for periodontal health, especially in the presence of restorative and/or prosthetic margins invading these structures ${ }^{1,2}$. Violation of this tissue will result in progressive inflammation in which the organism, at the expense of bone resorption, promotes restoration of the invaded dimensions ${ }^{2}$. Clinically, these changes may be observed as 
gingival retraction or periodontal pocket formation ${ }^{1}$.

The new classification of periodontal diseases and conditions detailed that the region composed of connective insertion and junctional epithelium around the tooth circumference is defined as supracrestal tissue attachment ${ }^{3}$. This anatomical area was previously described as a biological space ${ }^{4}$. To maintain the biophysiological integrity of this anatomical area, 3 to $4 \mathrm{~mm}$ of healthy dental structure coronal to the alveolar bone crest are required. Maintenance of this distance is necessary to avoid mechanical trauma of restorations on the periodontal supporting structures, with consequent migration and apical reorganization of these structures ${ }^{3,4}$.

The clinical restoration of this invaded supracrestal tissue attachment can be achieved by surgical techniques to increase the clinical crown, based on gingivectomy and alveolar bone resection by osteotomy/osteoplasty or by more conservative maneuvers as root traction or also by the association of both techniques ${ }^{5}$.

The possibility of root traction is based on the combination of endodontic-orthodontic treatment in which the tooth is displaced in the direction of its eruption to restore the lost biological dimensions, optimizing the adaptation of restorations and/or dentures within biological limits $^{5}$. The technique of traction or dental extrusion, when properly indicated, provides a more favorable esthetic effect than surgery for clinical crown lengthening, providing less bone sacrifice in adjacent non-compromised teeth and esthetic deformity by increasing the crown/root ratio.

Thus, the objective of this narrative literature review is to identify whether root traction is capable of maintaining the periodontal health of teeth with invasion of supracrestal tissue attachment and prosthetically rehabilitated over time.

\section{MATERIAL AND METHOD}

This study was based on the guidelines for synthesis without meta-analysis (Synthesis Without Meta-analysis - SwiM), developed to guide reviews of interventions in which the metaanalysis of effect estimates is not possible or cannot be performed ${ }^{6}$.

The focused patient, intervention, comparison, and outcome (PICO) question for this study was "What are the effects obtained by root traction on the ability to maintain teeth with invasion of supracrestal tissue attachment and prosthetically rehabilitated, with periodontal health".
Six electronic databases (Scopus, PubMed, EMBASE, Web of Science, Scielo and Cochrane) were searched by two independent reviewers using the Mesh descriptors [orthodontic extrusions], [forced eruption] and [crown lengthening]. As inclusion criteria, studies published in English or Spanish, in national and international journals, and which presented the relationship between root traction and the effect on periodontal health in prosthetically rehabilitated teeth were considered. The survey included studies that presented root traction/extrusion treatment, prosthetic completion of the case and that also described longitudinal periodontal follow-up. Studies or articles with abstracts written in languages other than those aforementioned and that did not have concrete content with the research objective to be considered valid were excluded. The titles and abstracts of studies identified by the search strategies were evaluated by the reviewer and selected according to their relevance according to some criteria as type of study, root traction or orthodontic extrusion present, rehabilitation with single fixed prosthesis and period of clinical follow-up.

Data collection and extraction were independently performed by a pair of reviewers and, when there were disagreements in data collected, they were solved either by consensus between the pair or by consultation with a third reviewer. After the selection process was completed, a previous systematic, selective and analytical reading of studies included in the eligibility criteria was performed.

RESULTS

The searches conducted in the electronic databases established in the methodological description identified 644 articles and are detailed in the flowchart representing the studies (Figure 1).

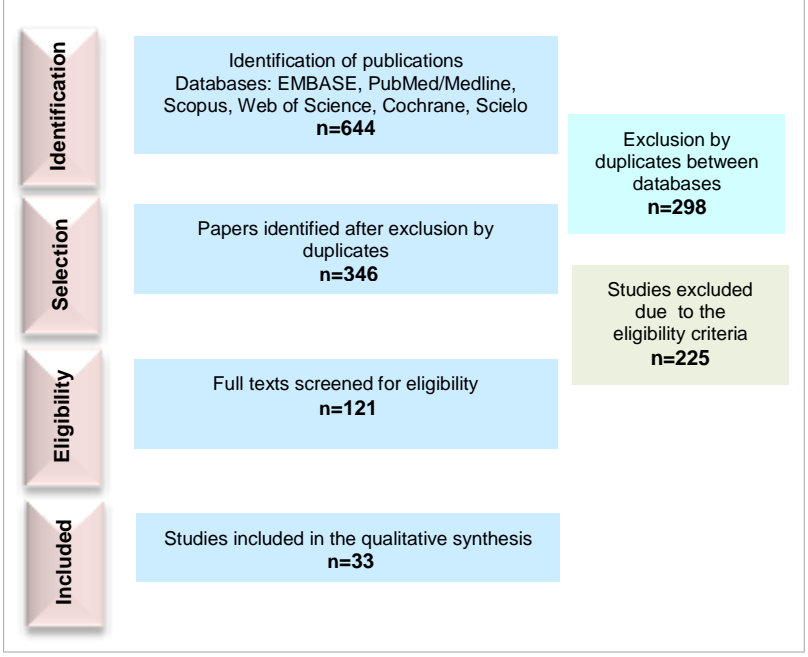

Figure 1: Search strategy. 
A total of 121 articles were selected after reading the titles and abstracts, using the inclusion and exclusion criteria. After reading the full text of selected papers, they were examined and after careful analysis of their contents 33 articles had potential for a more qualified analysis (Table I).

Table 1 - Characteristics of the included studies.

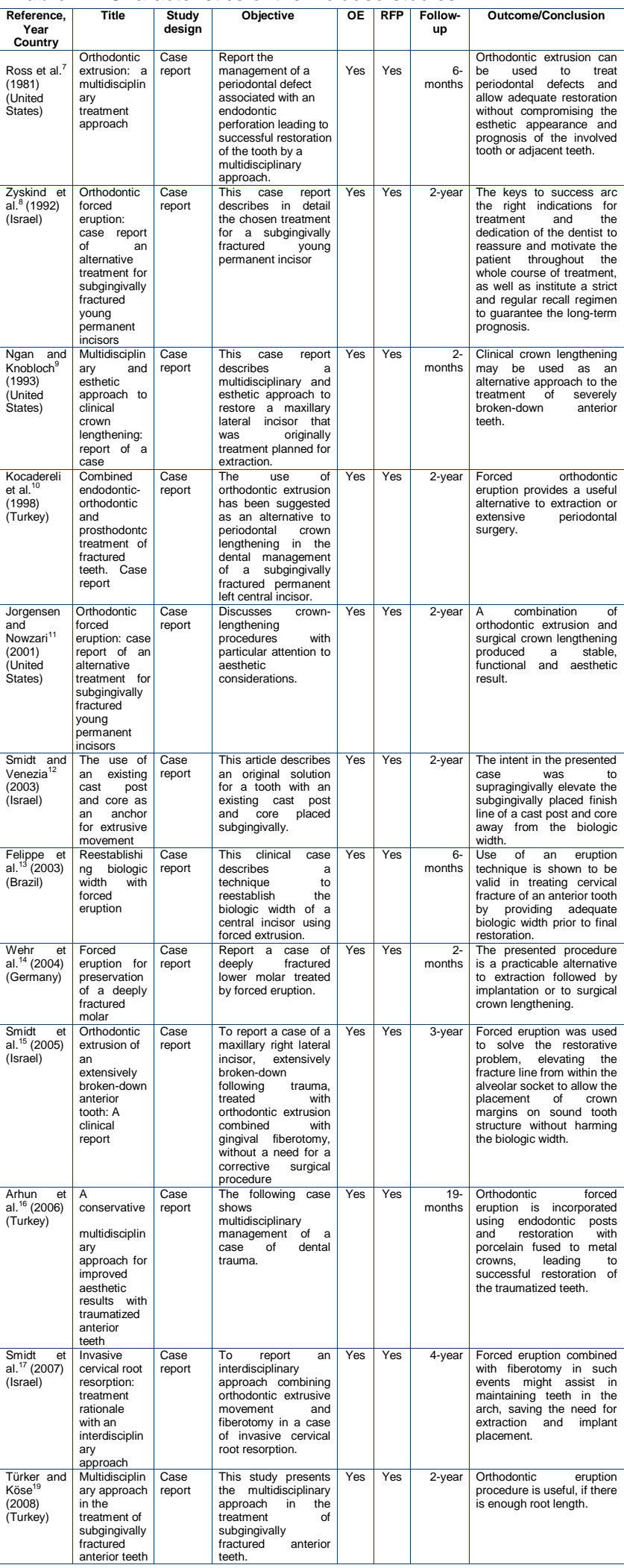

$\mathrm{OE}=$ Orthodontic Extrusion $; \mathrm{RFP}=$ Rehabilitation with Fixed Prothesis
Table 1 (continuation) - Characteristics of the included studies.

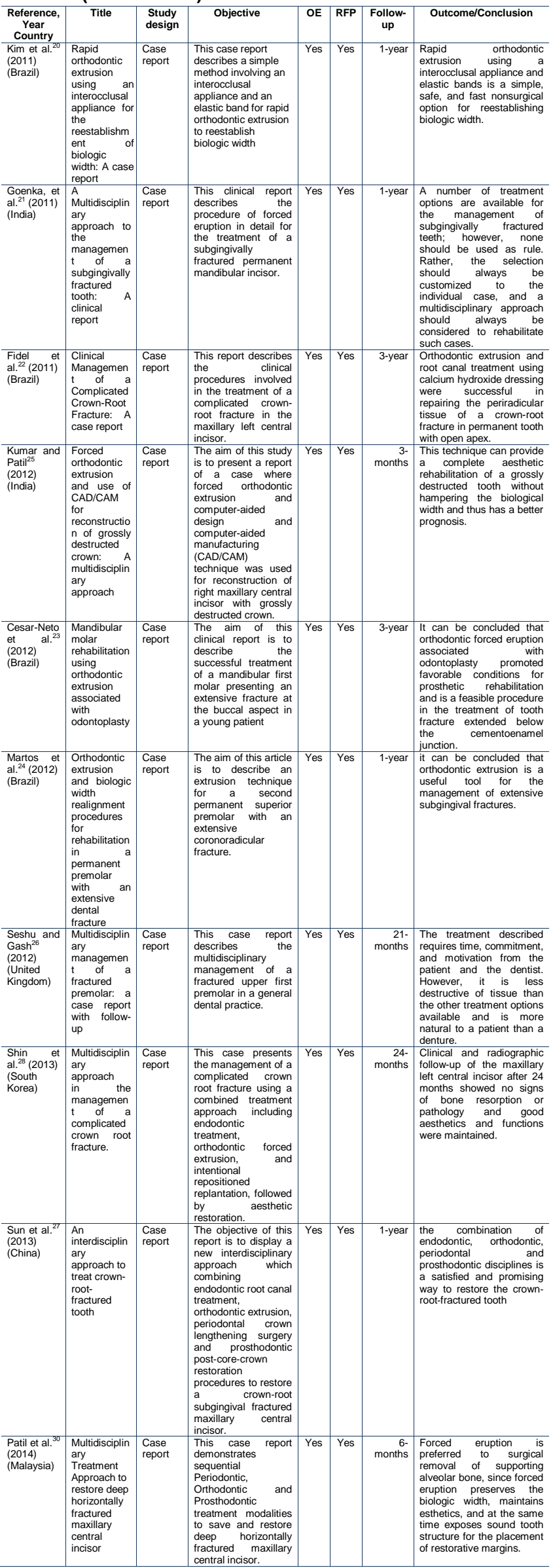

$\mathrm{OE}=$ Orthodontic Extrusion ; RFP = Rehabilitation with Fixed Prothesis 
Table 1 (continuation) - Characteristics of the included studies.

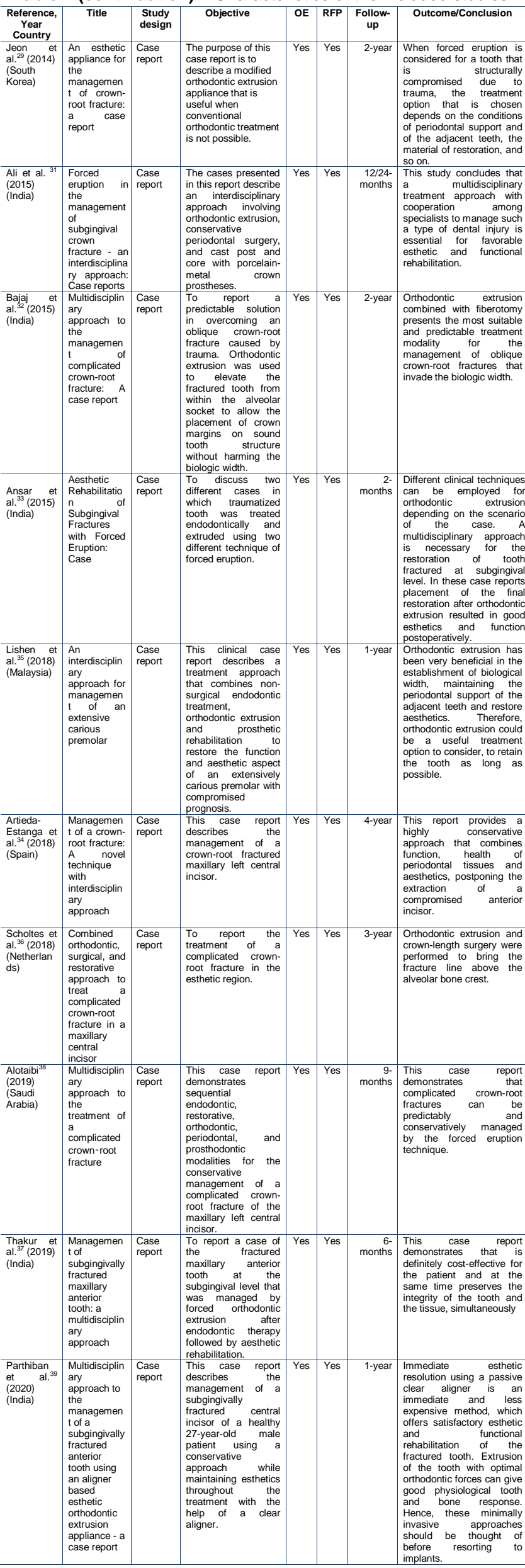

$\mathrm{OE}=$ Orthodontic Extrusion $; \mathrm{RFP}=$ Rehabilitation with Fixed Prothesis
DISCUSSION

The purpose of this study was to identify the relationship between root traction and its effects on periodontal health in prosthetically rehabilitated teeth. All parameters of periodontal health evaluated during follow-up, such as a periodontal result incompatible with health or inflammation of periodontal tissues, were analyzed for each tooth that had undergone extrusive root action due to tooth fracture or any other event that would lead to invasion of the supracrestal tissue attachment and required prosthetic rehabilitation. To reduce the possibilities of errors and/or mistakes during selection and evaluation of identified studies, the criteria for clinical follow-up after placement of the prosthetic element were adopted in an excluding manner. The clinical description in the texts were accurately observed, showing maintenance or not of periodontal health throughout the follow-up time, as an unequivocal condition after placement of the fixed denture, either by radiographic and/or clinical/periodontal methods. Studies that performed root traction, but that the restorative procedure involved the use of restorations with composite resins, were not included in our analysis since the presence of bacteria commonly found in the tooth/crown interface can be minimized by the adhesive nature of the restorations and this form would directly influence our assessment.

It is worth mentioning the use of SWiM guidelines in this review. This guideline is specifically related to reporting, in a transparent manner, the methods and results of the narrative synthesis of the effect estimates in reviews that incorporate several sources of data that are not subject to meta-analysis ${ }^{6}$.

From the analyzed studies, it was observed that orthodontic traction enabled a viable alternative to tooth extraction or more extensive periodontal surgery ${ }^{7-39}$. Root traction is preferable to surgical removal of the supporting alveolar bone, since the forced eruption preserves integrity of the supracrestal tissue attachment, the esthetics and simultaneously exposes the healthy dental structure for placement of restorative margins in a biophysiological situation ${ }^{5}$. It has been shown that greater loss of periodontal insertion is a direct consequence of clinical crown lengthening surgery where recovery of the supracrestal tissue attachment through osteotomy is necessary ${ }^{40}$. Maintaining a healthy dental element within the stomatognathic system is also important for subsequent implant placement, as it is essential to maintain dense bone to support an implant. 
Most that culminated in invasion of supracrestal insertion tissues observed in this review were due to trauma and dental fractures ${ }^{8-16,18-34,36-39}$; however, cases of external cervical resorption ${ }^{17}$ or even carious cervical lesions with invasion of supracrestal insertion tissues were also observed ${ }^{7,35}$. Anterior teeth corresponded to $82.8 \%$ of all teeth treated in these studies, 4 teeth were upper premolars $^{12,24,26,35}$ and only 2 studies reported this treatment approach in lower molars ${ }^{14,23}$. Orthodontic extrusion, combined or not with fibrotomy, presented the most conservative and predictable treatment option for the management of oblique coronal fractures that invaded the supracrestal insertion tissues according to almost all studies evaluated. The International Association of Dental Traumatology (IADT) recommends orthodontic extrusion of the apical segment for cases of dental fractures complicated with invasion of periodontal structures as a therapeutic approach ${ }^{41}$. This study highlighted that many cases of dental trauma solved with this approach of root traction were not included in the qualitative synthesis because they were finished with bonding of dental fragments or composite resin restorations, rather than prosthetic rehabilitation.

It can be noted that all studies evaluated were case reports and showed full success, among other factors, due to the clinical followup, assuring the good prognosis of the rehabilitation treatment in the long term. A satisfactory prosthetic rehabilitation, associated with periodontal health after root traction, could be observed in all studies, notably with variation in the follow-up time observed in the first six months $s^{7,9,13,14,18,25,30,33,37,} 9$ months $^{38}$, 1 year $^{20,21,24,27,35,39}$, between 19 and 21 months ${ }^{16,26}$, and also in those maintaining a strict follow-up regime of 2 years ${ }^{8,10,11,12,19,28,29,31,32}, 3$ years ${ }^{15,20,23,36}$ and even up to 4 years of followup $^{17,34}$.

Another interesting aspect is that root traction in most studies (88\%) presented orthodontic apparatus to activate the root extrusion mechanism; however, some studies used non-orthodontic appliances, e.g. occlusal acrylic plates ${ }^{20,29,39}$ or even magnets attached to the traction mechanism ${ }^{18}$. The mean time of root traction for the different evaluated cases varied according to the technique used, whether fast or slow, the appliance used or depending on each individual case concerning the amount of traction required. This period varied from 1 to 2 weeks $^{13,18,20,33}, 3$ to 5 weeks $^{11,12,15,21,25,29,32}, 6$ to 8 weeks $^{8,9,10,14,16,19,26,28,30,31,34,35,38,} \quad 9$ to 12 weeks $^{7,23,27}$ and also over 13 weeks $^{22,24,36,37,39}$.
Cases evaluated with longer maintenance of the traction appliance were due to association between the active period and the retention period.

Root traction is a simple, safe and fast non-surgical option to restore the biological dimensions of the periodontium. Root traction with ideal orthodontic forces provides a good physiological response to both tooth and bone tissue. This minimally invasive approach must be considered before indicating dental implants ${ }^{39}$. The therapeutic approach should aim at the exposure of subgingival margins of the fractured tooth without compromising the supracrestal tissue attachment. Different from other orthodontic procedures, besides not causing bone resorption, the extrusion promotes additional bone deposition lining the alveolus ${ }^{37}$.

It can also be highlighted that it was not possible to identify studies where there was eventual periodontal inflammation during followup, i.e. cases where root traction followed by prosthetic rehabilitation showed failure from a periodontal standpoint. The effects of root traction on the maintenance of periodontal health of teeth with invasion of supracrestal tissue attachment and prosthetically rehabilitated were observed in all studies, thus showing clinical success. Notwithstanding, it is important to emphasize that the clinical evaluations used in longitudinal follow-ups in most studies were conducted by periapical radiographic examination and visual aspect of the gingival tissue by photographic image. Monitoring of periodontal clinical parameters of probing depth and clinical attachment level, as well as the gingival index, were not presented. In addition, no important factors have been reported that could influence the gingival inflammatory process, such as the presence of behavioral and systemic risk factors, susceptibility, and history of periodontal disease in individuals.

In this respect, the only variation observed in this narrative synthesis and how they could affect the conclusions related to the question of the original review refer only to the time of clinical follow-up.

Root traction should be offered to the patient, as long as the indication is met, as a fully viable option before making a decision for more radical procedures as resective bone surgeries for clinical crown lengthening or extraction/implant ${ }^{38}$. Nothing compares to the natural compatibility and proprioception of the root to the alveolar bone tissue. The indication of implants instead of compromised teeth should be guided by clinical signs that indicate a 
superior result or greater predictability. The indication for maintenance or extraction of a tooth should be based on the clinical and periodontal status, the available scientific evidence and also the patient's objectives and/or expectations.

CONCLUSION

It can be concluded, by the studies included in this narrative literature review, that root traction is a conservative and effective tool in the treatment of teeth with invasion of supracrestal tissue attachment and prosthetically rehabilitated and is capable of maintaining the periodontal health over time.

\section{REFERENCES}

1. Parma-Benfenati S, Fugazzotto PA, Ruben MP. The effect of restorative margins on the postsurgical development and nature of the periodontium. Int J Periodont Rest Dent.1985; $5(6): 30-52$.

2. Wagenberg BD. Exposing adequate tooth structure for restorative dentistry. Int $\mathrm{J}$ Periodont Rest Dent. 1989;9(5):323-31.

3. Jepsen S, Caton JG, et al. Periodontal manifestations of systemic diseases and developmental and acquired conditions: consensus report of workgroup 3 of the 2017 World Workshop on the Classification of Periodontal and Peri-Implant Diseases and Conditions. J Clin Periodontol. 2018;45(Suppl 20):S219-29.

4. Maynard G, Wilson RDK. Physiologic dimensions of the periodontium significant to the restorative dentistry. J Periodontol. 1979; 50(4):170-74.

5. Heithersay GS. Combined endodonticorthodontic treatment of transverse root fractures in the region of the alveolar crest. Oral Surg Oral Med Oral Pathol. 1973;36(3):404-15.

6. Campbell M., et al. Synthesis without metaanalysis (SWiM) in systematic reviews: reporting guideline BMJ. 2020;368:16890.

7. Ross S, Dorfman HS, Palcanis KG. Orthodontic extrusion: a multidisciplinary treatment approach. J Am Dent Assoc. 1981;102(2):189-91.

8. Zyskind K, Zyskind D, Aubrey Soskolne W, Harary D. Orthodontic forced eruption: Case report of an alternative treatment for subgingivally fractured young permanent incisors. Quintessence Int. 1992;23(6):393-99.

9. Ngan, P, Knobloch, L. Multidisciplinary and esthetic approach to clinical crown lengthening: Report of a case. Quintessence Int. 1993; 24(12):835-39.

10. Kocadereli I, Taşman F, Güner SB. Combined endodontic-orthodontic and prosthodontic treatment of fractured teeth. Case report. Aust Dent J.1998;43(1):28-31.
11.Jorgensen MG, Nowzari H. Aesthetic crown lengthening. Periodontol 2000. 2001;27(1): 45-58.

12. Smidt $A$, Venezia $E$. The use of an existing cast post and core as an anchor for extrusive movement. Int J Prosthodont. 2003;16(3): 225-28.

13. Felippe LA, Monteiro Jr S, Vieira LCC, Araujo E. Reestablishing biologic width with forced eruption. Quintessence Int. 2003;34(10): 733-38.

14. Wehr C, Roth A, Gustav M, Diedrich P. Forced eruption for preservation of a deeply fractured molar. J Orofac Orthop. 2004;65(4):343-54.

15. Smidt A, Lachish-Tandlich M, Venezia E. Orthodontic extrusion of an extensively broken down anterior tooth: A clinical report. Quintessence Int. 2005;36(2):89-95.

16. Arhun N, Arman A, Ungor M, Erkut S. A conservative multidisciplinary approach for improved aesthetic results with traumatised anterior teeth. Br Dent J. 2006; 201(8):509-12.

17. Smidt A, Nuni E, Keinan D. Invasive cervical root resorption: Treatment rationale with an interdisciplinary approach. J Endod. 2007; 33(11):1383-87.

18. Mehl C, Wolfart S, Kern M. Orthodontic extrusion with magnets: A case report. Quintessence Int. 2008;39(5):371-79.

19. Türker SB, Köse KN. Multidisciplinary approach in the treatment of subgingivally fractured anterior teeth. Dent Traumatol. 2008;24(2): 239-43.

20. Kim SH, Tramontina VA, Papalexiou V, Luczyszyn SM, Grassi MB, De Fatima Scarpim M, Tanaka OM. Rapid orthodontic extrusion using an interocclusal appliance for the reestablishment of biologic width: A case report. Quintessence Int. 2011;42(3):201-4.

21. Goenka P, Marwah N, Dutta S. A multidisciplinary approach to the management of a subgingivally fractured tooth: A clinical report. J Prosthodont. 2011;20(3):218-23.

22. Fidel SR, Fidel-Junior RAS, Sassone LM, Murad CF, Fidel RAS. Clinical management of a complicated crown-root fracture: A case report. Braz Dent J. 2011;22(3):258-62.

23. Cesar-Neto JB, Martos J, Artifon L, Silveira LFM, Michelon D, Masotti AS, Silva JCM. Mandibular molar rehabilitation using orthodontic extrusion associated with odontoplasty. J Prosthodont. 2012;21(8): 626-30.

24. Martos J, de Moraes A, Carlos C, Nova Cruz LE, Silveira LF. Orthodontic extrusion and biologic width realignment procedures for rehabilitation in a permanent premolar with an extensive dental fracture. J Interdiscip Dent. 2012;2(3):221-24 . 
25. Kumar R, Patil S. Forced orthodontic extrusion and use of CAD/CAM for reconstruction of grossly destructed crown: A multidisciplinary approach. J Conserv Dent. 2012;15(2):191-95.

26. Seshu MRK, Gash CL. Multidisciplinary management of a fractured premolar: A case report with follow-up. Case Rep Dent. 2012:1-4.

27. Sun YC, Li Y, Tong J, Gao P. An interdisciplinary approach to treat crown-rootfractured tooth. Niger Med J. 2013;54(4):274-7.

28.Shin JH, Kim JE, Kim RJ. Multidisciplinary approach in the management of a complicated crown root fracture. Europ J Paediatr Dent. 2013;14(2):150-52.

29. Jeon SM, Lee $\mathrm{KH}$, Jung BY. An esthetic appliance for the management of crown-root fracture: a case report. Restor Dent Endod. 2014;39(3):226-29.

30. Patil PG, Nimbalkar-Patil SP, Karandikar AB. Multidisciplinary treatment approach to restore deep horizontally fractured maxillary central incisor. J Contemp Dent Pract 2014.15(1): 112-15.

31. Ali S, Zoya A, Mian F. Forced eruption in the management of subgingival crown fracture - an interdisciplinary approach: Case reports. Dent Med Probl. 2015;52(3):371-76.

32. Bajaj P, Chordiya $R$, Rudagi K, Patil N. Multidisciplinary approach to the management of complicated crown-root fracture: a case report. J Int Oral Health. 2015;7(4):88-91.

33. Ansar J, Jain P, Bhattacharya P, Agarwal DK. Aesthetic rehabilitation of subgingival fractures with forced eruption: Case reports. J Clin Diagn Res. 2015;9(5):13-5.

34. Artieda-Estanga A, Castelo-Baz P, Bello-Castro A, Ramos-Barbosa I, Martin-Biedma B, BlancoCarrion J. Management of a crown-root fracture: A novel technique with interdisciplinary approach. J Clin Exp Dent. 2018;10(6):620-23.

35. Lishen, W, In Meei, T, Marny Mohamed, A, Abdullah, D. An interdisciplinary approach for management of an extensive carious premolar. Iran Endod J. 2018;13(3):403-6.

36. Scholtes E, Suttorp CM, Loomans BA, Van Elsas PA, Schols JG. Combined orthodontic, surgical, and restorative approach to treat a complicated crown-root fracture in a maxillary central incisor. Am J Orthod Dentofacial Orthop. 2018;154(4):570-82.

37. Thakur A, Arora KS, Kaur K, Dahiya S. Management of subgingivally fractured maxillary anterior tooth: A multidisciplinary approach. BMJ Case Rep. 2019;12(7):10-2.

38. Alotaibi, B. Multidisciplinary approach to the treatment of a complicated crown-root fracture. Saudi Endod J. 2019;9(1):56-60.

39. Parthiban G, Nagesh S, Karale R, Reddy S. Multidisciplinary approach to the management of a subgingivally fractured anterior tooth using an aligner based esthetic orthodontic extrusion appliance - A case report. Saudi Endod J. 2020;10(2):157-61.

40.Oppermann RV, Gomes SC, Cavagni J, Cayana EG, Conceição EN. Response to proximal restorations placed either subgingivally or following crown lengthening in patients with no history of periodontal disease. Int J Periodontics Restorative Dent. 2016; 36(1):117-24.

41.Bourguignon C. et al. International Association of Dental Traumatology guidelines for the management of traumatic dental injuries: 1. Fractures and luxations. Dent Traumatol. 2020; 36(4):314-30.

\section{CONFLICTS OF INTERESTS}

The authors declare no conflicts of interests.

\section{CORRESPONDING AUTHOR}

\author{
Josué Martos \\ Department of Semiology and Clinics, \\ School of Dentistry, \\ Federal University of Pelotas, Brazil. \\ Gonçalves Chaves st., 457 \\ 96015-560 - Pelotas - RS, Brazil \\ Phone: +55 5332214162 \\ e-mail: josue.sul@terra.com.br
}

